\title{
Detection of habitats colonized by Omphiscola glabra (Gastropoda: Lymnaeidae) on acid soils using indicator plants
}

\author{
Philippe Vignoles, Gilles Dreyfuss* and Daniel Rondelaud \\ Laboratory of Parasitology, Faculty of Pharmacy, 87025 Limoges Cedex, France
}

Received 31 January 2017; Accepted 20 April 2017

\begin{abstract}
The lymnaeid Omphiscola glabra is known to be an intermediate host in the life cycle of Fasciola hepatica and knowing its distribution in the field is important to determine that of the parasite. Looking at indicator plants has been proposed by several authors as one of the most practical ways of carrying out a malacological survey in pastures of a farm. Field investigations on 361 French farms breeding cattle or sheep on acid soils were thus carried out for 36 years in March or April to list indicator plant species in seven types of habitats colonized by $O$. glabra, and determine the characteristics of their habitats (area, snail density) for each indicator plant. Six plant species: Agrostis stolonifera, Dactylis glomerata, Glyceria fluitans, Juncus acutiflorus, Juncus effusus and Lotus uliginosus, were examined in 3137 snail habitats. J. effusus was the best indicator species to detect snail populations in five habitat types, while J. acutiflorus was the best indicator for snail populations living in spring heads. The other four plant species characterized only a few populations. Snail habitats detected with J. acutiflorus, J. effusus or L. uliginosus were significantly larger in area, while the density of overwintering snails was significantly lower in habitats with $G$. fluitans. These initial results suggest that $J$. effusus is a good indicator for the detection of $O$. glabra in the acid soils of central France. However, additional studies are required to test its limitations in the field.
\end{abstract}

Key words: Acid soil / habitat / indicator plant / Lymnaeidae / Omphiscola glabra

\section{Introduction}

The lymnaeid snails Galba truncatula (O.F. Müller) and Omphiscola glabra (O.F. Müller) act as intermediate hosts in the transmission of fasciolosis. The first species is known to be the main host snail of Fasciola hepatica (Linnaeus) in Western European countries (Torgerson and Claxton, 1999; Mas-Coma et al., 2009). In contrast, O. glabra is only an occasional intermediate host whose role has been mainly demonstrated on the acid soils of central France (Abrous et al., 1999, 2000). To control this parasitosis, it is necessary to treat livestock to eliminate adult flukes and also to control the host snail in its habitats. The search for G. truncatula and $O$. glabra populations in the field is always difficult because of the numerous temporary or permanent water bodies that these snails can colonize on acid soils. Looking at indicator plants was proposed by Over $(1962,1967)$ as one of the most practical ways to do a malacological survey in pastures of a farm with an animal fasciolosis problem. This idea was based on observations that De Brie (1379)

\footnotetext{
*Corresponding author: gilles.dreyfuss@unilim.fr
}

had made in French pastures. According to this author, there was a real danger for sheep to graze in a field with many buttercups of the species Ranunculus flammula (Linnaeus). The subsequent authors have provided contradictory results on the role of buttercups as indicator plants. Charlier et al. (2014) found a positive correlation between the presence of Ranunculus sp. and the abundance of G. truncatula on four Belgian farms. In contrast, Taylor (1965), in his review on fasciolosis, stated that the presence of these buttercups in a meadow did not mean that there was a real habitat for the snail. In central France, Guy et al. (1996) also found no relationship between the presence of these plants and the abundance of the snail in its habitats on acid soils.

In the swampy meadows and road ditches on the cristallophyllian soils of Limousin (central France), the populations of $G$. truncatula and $O$. glabra were often present in the same open drainage furrows: the peripheral extremity of these furrows was colonized by G. truncatula, while the middle part was occupied by the other lymnaeid (Vareille-Morel et al., 1999, 2007; Rondelaud et al., 2009). Given this situation, it was logical to assume that the indicator plants used for the detection of $G$. truncatula 
habitats could be the same to identify habitats where O. glabra lives. Several authors such as Patzer (1927) and Mehl (1932) in Germany or de Vries (1945) and Roberts (1950) in Great Britain have already provided several lists of indicator plants to identify the habitats of G. truncatula. According to Smith (1978) and Moens (1981), the habitats of this lymnaeid in Western Europe can be identified by associations of several helophytic plants. Among these, the presence of Alopecurus geniculatus (Linnaeus), Glyceria sp. and Ranunculus repens (Linnaeus) would be typical (Anderson, 2013). On the acid soils of Limousin, several species such as Juncus acutiflorus (Ehrhart, ex Hoffmann) or Juncus effusus (Linnaeus) have already been reported as indicator plants to detect the habitats of G. truncatula in swampy grasslands (Ghestem et al., 1974; Gaultier et al., 1994; Guy et al., 1996). Several species of Poaceae also had indicator value on the banks of ponds and rivers (Dreyfuss et al., 1997; Hourdin et al., 2006). In view of these preliminary results, it was considered interesting to undertake large-scale malacological investigations in Limousin to verify whether the use of these indicator plants truly enabled detection of the habitats of G. truncatula and those of $O$. glabra on farms with an animal fasciolosis problem.

Field investigations were thus carried out by our team on 361 cattle- or sheep-breeding farms located in Limousin to detect the habitats colonized by either lymnaeid, and to determine the characteristics of these habitats (surface area, snail density) in relation to each indicator plant species. The results obtained for G. truncatula have been published (Rondelaud et al., 2011). We found that $J$. acutiflorus was the most frequent indicator plant to detect the habitats of this snail, as this rush was found in most sites at the peripheral extremity of open drainage furrows and also in spring heads, trampled areas and road ditches. J. effusus was the most indicative species for snail sites located along drainage ditches, while Glyceria fluitans (R. Brown) was the most representative species for sites along the banks of ponds and rivers. The present paper reports the results we obtained on the habitats of $O$. glabra on the same soil type.

\section{Materials and methods}

\section{Study area}

Snail investigations were carried out by our team on 361 farms located in the three departments of Limousin (Fig. 1), i.e. northern Corrèze (71 farms), Creuse (56) and Haute Vienne (234). These farms were located in an area with GPS coordinates ranging from $45^{\circ} 20^{\prime} \mathrm{N}$ to $46^{\circ} 24^{\prime} \mathrm{N}$ in latitude and from $0^{\circ} 37^{\prime} \mathrm{E}$ to $2^{\circ} 8^{\prime} \mathrm{E}$ in longitude. All these farms were on cristallophyllian or metamorphic soils and $97.5 \%$ of them ranged from 190 to $500 \mathrm{~m}$ in altitude. Permanent grasslands on these farms were hygromesophilous: the hygrophilous zone of each meadow mainly consisted of rushes or bulrushes and covered the bottom of a valley, while the mesophilous zone was peripheral and extended on the nearest slopes (Fig. 2). These meadows were subject to an alternate regime of pasture and mowing. An open drainage network was generally present in these pastures. All these farms have a continental climate modulated by moist winds from the Atlantic Ocean. Depending on the year, average annual rainfall range from 800 to $1000 \mathrm{~mm}$, while the average annual temperature was between $10.5^{\circ} \mathrm{C}$ and $11.5^{\circ} \mathrm{C}$ according to the altitude of farms (Fig. 3). Snail habitats were waterlogged from early October until late May or early June and were subject to drying out from early July to mid-September.

Two successive malacological surveys were carried out in March or April in each farm and its immediate vicinity. The first was carried out between 1970 and 1999 when one or more cases of fasciolosis were detected by the local veterinarians in cattle or sheep. A total of 11992 water holes in the 361 farms were investigated during this survey to identify the presence/absence of an indicator plant species, determine lymnaeid species and specify habitat size when snails were present. The second survey was performed between 1976 and 2006 when new cases of fasciolosis were detected. The 3137 populations of O. glabra recorded on these 361 farms during the first survey were re-investigated to count overwintering snails and calculate the surface area of each habitat.

These investigations were carried out in permanent meadows and road or way ditches, which edged them. They were also done along the borders of evacuation systems, i.e. pond, stream and river banks. The total area investigated on these 361 farms was $385.7 \mathrm{~km}^{2}$ (Vareille-Morel et al., 2007). March and April were chosen because all snail sites were watered and vegetation was sufficient to identify the species of Poaceae.

\section{Potential indicator plants}

Six species: J. acutiflorus, J. effusus, Lotus uliginosus (Schkuhr), Agrostis stolonifera (Linnaeus), Dactylis glomerata (Linnaeus) and G. fluitans, were used as potential indicator plants. The first three were selected as they represented more than $75 \%$ of plant species found by Ghestem et al. (1974), Gaultier et al. (1994) or Guy et al. (1996) during their phytosociological studies in swampy pastures on acid soils. In road ditches, both rush species, A. stolonifera and G. fluitans were chosen according to their dominance in the study by Jourdin et al. (1985) on the habitats of these lymnaeids in northern Haute Vienne. The dominance of D. glomerata and G. fluitans over the other plant species in sites with $G$. truncatula along two rivers (Dreyfuss et al., 1997; Hourdin et al., 2006) was the reason for their selection as potential indicator plants on the pond and river banks.

The dominance of one plant over the other species was determined according to the criteria used by the Zürich-Montpellier school of phytosociology (Becking, 1957). When the dominance of J. acutiflorus and that of $J$. effusus over the other plant species were the same in a snail habitat, these two rush species were considered as indicator plants for this habitat. 


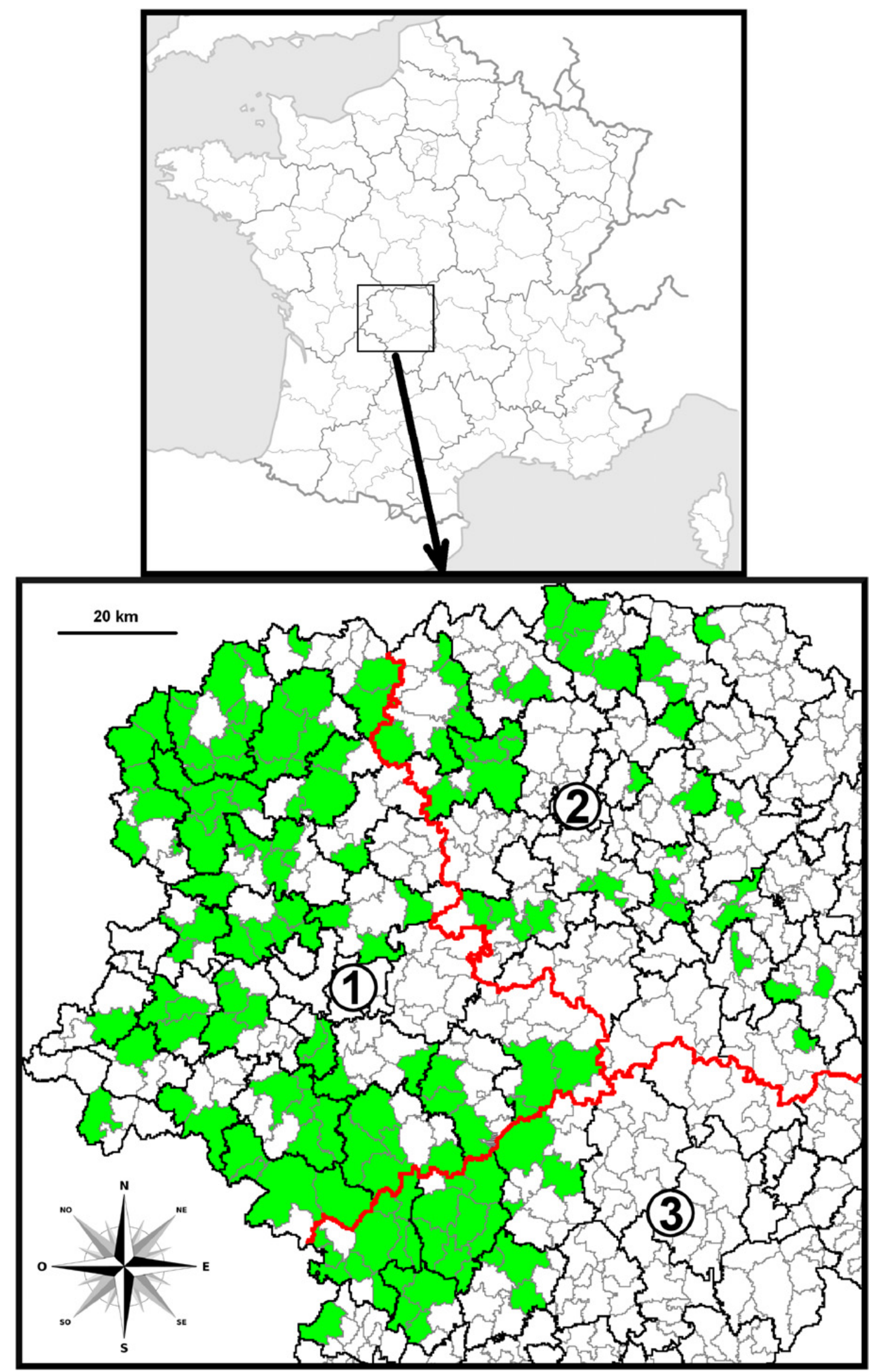

Fig. 1. Location of the Limousin region in France (upper map) and municipalities (in green) on which the 361 farms investigated are located (lower map): 1, Haute Vienne; 2, Creuse; 3, northern Corrèze. In red, the administrative limit between the three departments. 


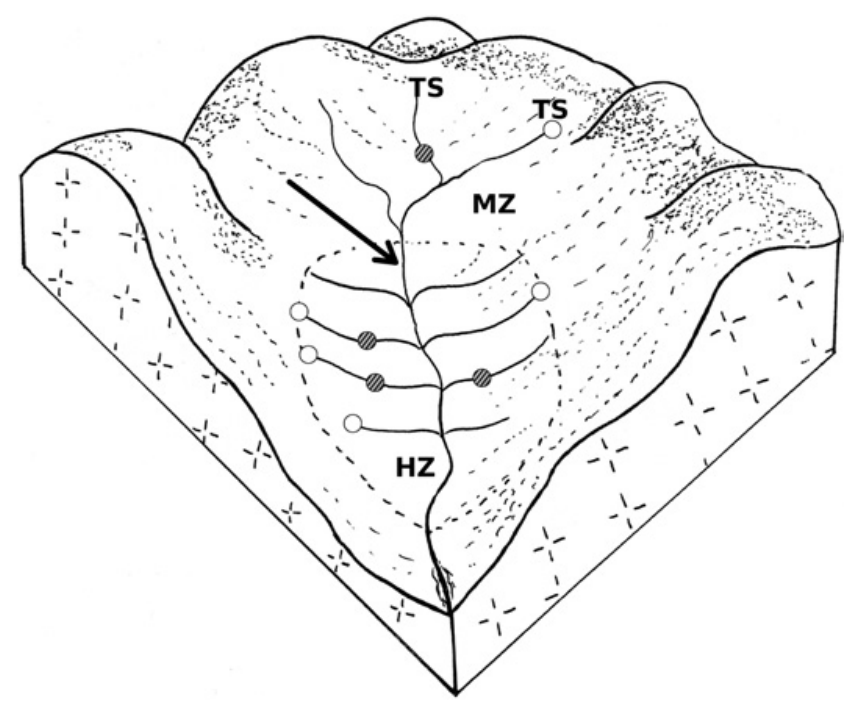

Fig. 2. Block diagram showing the location of Omphiscola glabra $(\bullet)$ and Galba truncatula $(\circ)$ habitats along an open drainage network on the Limousin acid soils. The HZ in each meadow covers the bottom of the valley, while the MZ is peripheral and extends to the nearest slopes. The drainage ditch (arrow) receives water from several furrows. The snail habitats are located at the end of these furrows (G. truncatula) or in the middle part of their course $(O$. glabra). HZ, hygrophilous zone; MZ, mesophilous zone; TS, temporary spring.



Fig. 3. Ombrothermic diagram showing the monthly variations of rainfall (histograms) and temperature (continuous line) throughout the year in northern Haute Vienne. Mean values of temperature are given with their range. All data came from records noted from 1981 to 2010 by the meteorological station at Le Dorat, department of Haute Vienne. Temperature in ${ }^{\circ} \mathrm{C}$, rainfall in $\mathrm{mm}$.

\section{Snail investigations}

When an indicator plant, either in monospecific stands, or as the dominant species in multi-species assemblages, was found near a water hole, the corresponding area was investigated for the presence of the snail. Seven types of habitats were considered for O. glabra. The first four were located in meadows: (i) surface drainage furrows, (ii) temporary or permanent spring heads on hillsides, (iii) surface drainage ditches and (iv) trampled areas when they were covered by a water layer of at least $5 \mathrm{~cm}$ in depth. The other three types were (v) road or way ditches when they are waterlogged during winter and spring, (vi) small streams and (vii) ponds.

In each habitat, the abundance of the O. glabra population was evaluated by counting overwintering snails because this generation consisted mostly of adult snails ( $>12 \mathrm{~mm}$ shell height) in March or April that had not yet laid their egg masses at that time. Depending of the water level, these snails were counted on sight or after collection with a sieve ( $3 \mathrm{~mm}$ mesh size) on the entire body of water. When the habitat was located on a meadow, the snails were counted by two people for $30-40 \mathrm{~min}$. In contrast, the snail count was performed by a single person for 15-20 min when the habitat was in a road ditch, on a pond bank or a stream bank. The surface area of each habitat was then determined. Measuring of areas occupied by snails was not difficult in the case of furrows, ditches, ponds and streams. Snail habitats located in spring heads and trampled areas were mapped and their areas were determined according to their geometric shape and size.

\section{Parameters studied}

The first parameter was the number of snail populations for each habitat type and each indicator species. The differences between the numbers recorded for the different plant species within the same habitat type were analyzed using Fisher's exact test. The fisher.multcomp function of the RVAideMemoire package (R Core Team, 2016) was used as a post hoc test to perform pairwise comparisons. The other two parameters were the surface area of each habitat and the number of overwintering snails per $\mathrm{m}^{2}$ of habitat. Individual values noted for either parameter were averaged and standard deviations were established, taking into account the indicator plant. Normality of these values was analyzed using a Shapiro-Wilk normality test (Shapiro and Wilk, 1965). As the distributions of these values were not normal, a Kruskal-Wallis test was used to establish levels of significance. All the statistical analyses were performed using R 3.3.0 software (R Core Team, 2016).

The surface areas of snail habitats and snail densities shown in Table 3 correspond to the set of results for each indicator plant and do not take into account the habitat type. Figures 4 and 5 show the frequencies of habitats colonized by $G$. truncatula and $O$. glabra in relation to their surface area or their snail density, respectively, and the presence of four indicator plants (G. fluitans, $J$. acutiflorus, J. effusus and L. uliginosus). As the data reported by Rondelaud et al. (2011) for G. truncatula were given using classes for habitat areas or snail densities, the areas of $O$. glabra habitats were presented using the 



Fig. 4. Frequency of habitats colonized by Omphiscola glabra (a) and Galba truncatula (b) in relation to their area in March or April and the presence of four indicator species on the Limousin acid soils. Total number of habitats identified with Juncus effusus, Juncus acutiflorus, Lotus uliginosus and Glyceria fluitans: O. glabra, 2784, 585, 25 and 16, respectively; G. truncatula, 538, 6541,51 and 357 . The data used for $G$. truncatula came from the report by Rondelaud et al. (2011).

following five categories: $<2 \mathrm{~m}^{2}$, from 2.1 to $5 \mathrm{~m}^{2}$, from 5.1 to $10 \mathrm{~m}^{2}$, from 10.1 to $20 \mathrm{~m}^{2}$ and $>20 \mathrm{~m}^{2}$. A similar protocol was used for the density of overwintering snails but with the following five categories: $<5$ snails $/ \mathrm{m}^{2}$, from 5.1 to $10 / \mathrm{m}^{2}$, from 10.1 to $15 / \mathrm{m}^{2}$, from 15.1 to $20 / \mathrm{m}^{2}$ and $>20 / \mathrm{m}^{2}$. The percentages presented in the histograms of each graph are expressed in relation to the total number of snail populations noted for each indicator plant species (i.e. $100 \%$ ).

\section{Results}

Table 1 shows the distribution of the 3137 snail populations according to the type of habitat colonized by this species. The most numerous populations ( $>20 \%$ of water holes studied) were located in open drainage furrows and road or way ditches. Intermediate values were recorded for snail colonies that lived in springs, drainage ditches and along pond banks, while the populations
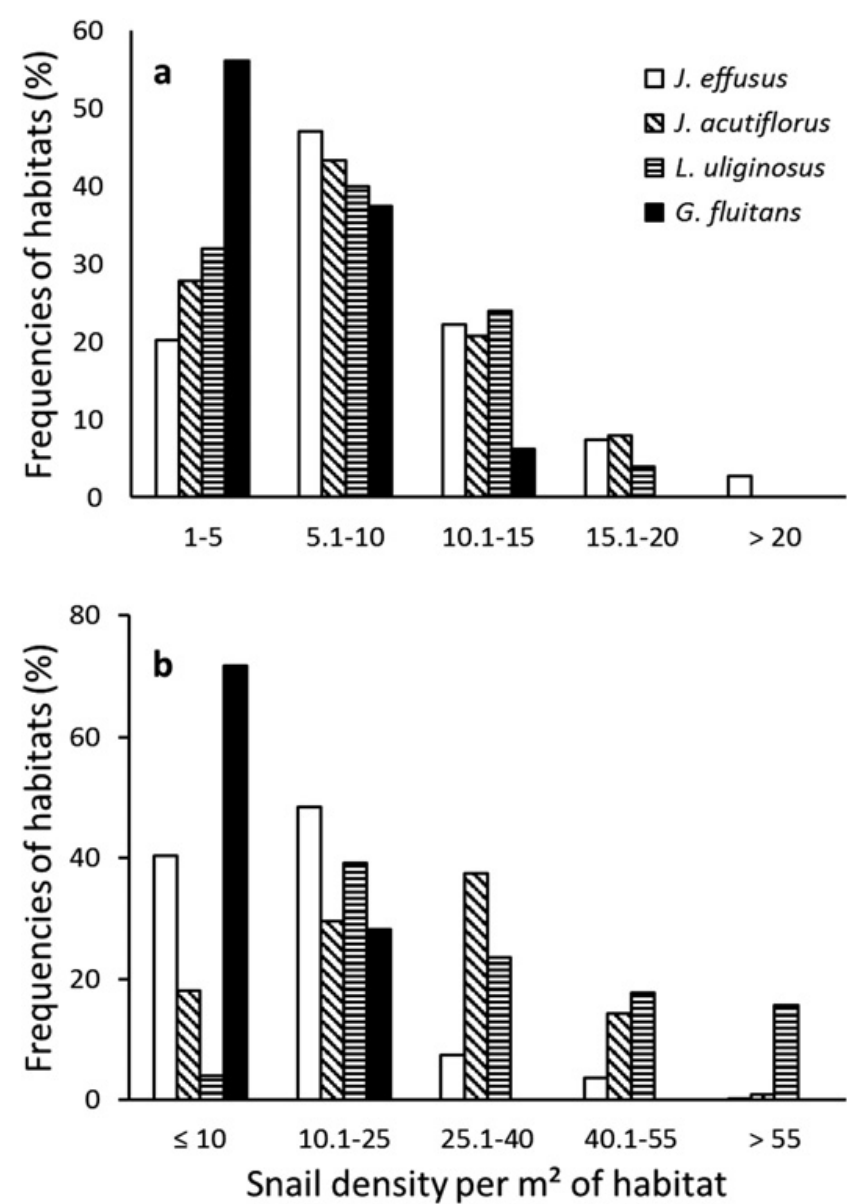

Fig. 5. Frequency of habitats colonized by Omphiscola glabra (a) and Galba truncatula (b) in relation to their density of overwintering snails in March or April and the presence of four indicator species on the Limousin acid soils. The total number of habitats identified with these indicator plants is given in the caption of Figure 4. The data used for G. truncatula came from the report by Rondelaud et al. (2011).

colonizing stream banks and trampled areas were less common $(<10 \%)$.

\section{Frequency of snail populations for each indicator plant}

The most frequent indicator species characterizing these snail populations was $J$. effusus (Table 2) because this rush was noted in the seven habitat types. Compared with the other indicator plants, the number of snail populations identified with $J$. effusus was significantly higher in drainage furrows $(P<0.001)$, road or way ditches $(P<0.001)$, drainage ditches $(P<0.001)$, pond banks $(P<0.001)$ and stream banks $(P<0.001)$. In the case of spring heads, the number of snail populations was significantly higher $(P<0.001)$ when the indicator plant was $J$. acutiflorus. Lastly, no significant difference between the numbers of populations identified with either rush species in trampled areas was noted. If we consider the 
Table 1. Water holes studied on the 361 farms on the Limousin acid soils, with indication of the number of habitats colonized by Omphiscola glabra.

\begin{tabular}{lcc}
\hline Type of water hole & Number of water points investigated & Number of habitats with $O$. glabra $(\%)$ \\
\hline Open drainage furrows & 5546 & $2165(39.0)$ \\
Road ditches & 1934 & $498(25.7)$ \\
Spring heads (meadows) & 1454 & $195(13.4)$ \\
Open drainage ditches & 1287 & $134(10.4)$ \\
Pond banks & 811 & $53(6.5)$ \\
Stream banks & 727 & $87(11.9)$ \\
Trampled areas & 233 & $5(2.1)$ \\
Total & 11992 & $3137(26.1)$ \\
\hline
\end{tabular}

Table 2. Distribution of the 3137 populations of Omphiscola glabra on the Limousin acid soils in relation to the habitat type and presence of the indicator plant species.

\begin{tabular}{|c|c|c|c|}
\hline \multirow[b]{2}{*}{ Type of water point (total number) } & \multirow[b]{2}{*}{ Indicator plant } & \multicolumn{2}{|c|}{ Populations of $O$. glabra } \\
\hline & & Number & Frequency $(\%)$ \\
\hline Open drainage furrows (2165) & Juncus effusus & 2044 & 94.4 \\
\hline \multirow{3}{*}{ Road or way ditches (498) } & J. acutiflorus & 33 & 6.6 \\
\hline & J. effusus & 387 & 77.7 \\
\hline & Agrostis stolonifera & 75 & 15.0 \\
\hline \multirow{2}{*}{ Spring heads in meadows (195) } & J. effusus & 127 & 65.1 \\
\hline & L. uliginosus & 1 & 0.5 \\
\hline \multirow[t]{3}{*}{ Drainage ditches (134) } & J. acutiflorus & 21 & 15.6 \\
\hline & J. effusus & 106 & 79.1 \\
\hline & L. uliginosus & 7 & 5.2 \\
\hline Pond banks (53) & J. acutiflorus & 3 & 5.6 \\
\hline Stream banks (87) & G. fluitans & 2 & 2.2 \\
\hline \multirow[t]{2}{*}{ Trampled areas (5) } & J. acutiflorus & 3 & 60.0 \\
\hline & J. effusus & 5 & 100 \\
\hline
\end{tabular}

other indicator species within the same habitat type, the second plant dominating by the number of identified populations was $J$. acutiflorus in drainage furrows $(P<0.001), \quad A$. stolonifera in road or way ditches $(P<0.001), J$. acutiflorus in drainage ditches $(P<0.01)$, $J$. effusus in spring heads $(P<0.001)$ and $G$. fluitans on pond banks $(P<0.05)$.

The two rushes were found with the same dominance in three types of snail habitats located in pastures: 250 open drainage furrows, 104 springs and three trampled areas. In contrast, in the other habitats, only one indicator species (among the six mentioned above) was dominant in the surrounding vegetation (data not shown).

\section{Area of snail habitats for each indicator plant}

Table 3 shows the distribution of the 3137 snail habitats in relation to their surface area (measured in
March or April) and the presence of each indicator species. The mean areas noted in the habitats with $J$. acutiflorus or $J$. effusus were significantly larger $(P<0.01)$ than those identified with any of the other three indicator plants, whatever the mode of comparison. The differences between the areas of habitats identified with L. uliginosus and those of sites with D. glomerata or G. fluitans were also significant $(P<0.05)$. In contrast, the differences between the values for $J$. acutiflorus, J. effusus and L. uliginosus were not significant. The values found in habitats with A. stolonifera, D. glomerata or G. fluitans also did not significantly differ from each other.

\section{Density in snail habitats for each indicator plant}

The densities of overwintering snails noted in these habitats in March or April are also shown in Table 3 for each indicator plant. The values recorded in snail habitats 
Table 3. Distribution of 3137 habitats colonized by Omphiscola glabra in relation to their surface area or their density of overwintering snails in March or April and the presence of indicator plant species on the Limousin acid soils.

\begin{tabular}{lrrr}
\hline Indicator plant & Total number of snail habitats & ${\text { Habitat area }\left(\mathrm{m}^{2}\right)^{*}}$ & Snail density.m $^{-2 *}$ \\
\hline Juncus effusus & 2784 & $7.8 \pm 5.0$ & $10.0 \pm 4.4$ \\
Juncus acutiflorus & 585 & $6.9 \pm 4.4$ & $7.9 \pm 2.1$ \\
Lotus uliginosus & 25 & $6.2 \pm 3.5$ & $8.8 \pm 4.3$ \\
Glyceria fluitans & 16 & $3.6 \pm 2.4$ & $4.1 \pm 2.9$ \\
Agrostis stolonifera & 75 & $4.5 \pm 3.0$ & $9.5 \pm 3.2$ \\
Dactylis glomerata & 9 & $3.0 \pm 1.8$ & $8.6 \pm 4.5$ \\
\hline
\end{tabular}

$*$ Mean value \pm S.D.

identified with $G$. fluitans were significantly lower $(P<0.01)$ than those with any of the other five indicator plants. In contrast, the differences between the densities of snails in sites with A. stolonifera, D. glomerata, $J$. acutiflorus, J. effusus or L. uliginosus were not significant.

\section{Discussion}

The high frequencies noted in six habitat types of $O$. glabra identified with $J$. effusus show that this species is a good indicator for snail populations on the Limousin acid soils. Its presence near a water point often allows us to find $O$. glabra. However, J. effusus is often associated in the present study with $J$. acutiflorus in the same plant assemblages in meadows and road ditches. Under these conditions, further studies are needed to determine whether $J$. effusus can be used as the type indicator plant to detect any snail population in the other Western European countries on acid soils. Among the other five plants, J. acutiflorus was the best indicator species for snail populations living in spring heads. In these grasslands on acid soils, the variations noted in the frequencies of snail populations identified with $J$. acutiflorus or with J. effusus as indicator species can easily be explained by (i) the largest requirements of $J$. effusus towards moisture conditions in the soil (Botineau, 1985; Crowley et al., 2003), (ii) the need for packed soils for the growth of J. effusus (Brugel et al., 2001), and (iii) the fact that most springs in meadows were located in the mesophilous zone or at the boundary between the mesophilous and hygrophilous zones, as shown in Figure 2. In road ditches as on stream or pond banks, the presence of $J$. effusus indicates the existence of sufficient conditions for the development of O. glabra populations.

The mean areas noted in the snail habitats with $J$. acutiflorus or J. effusus were significantly larger than those identified with any of the other three indicator plants. This difference can be explained by the characteristics of each habitat type that the snail colonizes. Indeed, the most numerous areas identified in habitats with these rushes were noted in open drainage furrows and springs. As no information on the areas of habitats colonized by $O$. glabra in relation to the other indicator plant species is available in the literature, the values recorded for $O$. glabra in this study were compared with those that Rondelaud et al. (2011) have reported for some $G$. truncatula habitats located on the same farms and investigated during the same years. Figure 4 shows the distribution of areas recorded for snail habitats identified with G. Aluitans, J. acutiflorus, J. effusus or L. uliginosus because these values are the most numerous among those that our team recorded during the habitat detection using indicator plants. Surface areas noted for $O$. glabra were clearly higher than those of G. truncatula, whatever the area class considered. Two perhaps complementary explanations can be proposed to interpret this difference. The first is to relate it to the ecological requirements of each lymnaeid for water. G. truncatula is known to be an amphibious species and is commonly seen on emerged areas in spring and summer, while $O$. glabra is more aquatic with rare emergences from the water (Vignoles et al., 2017). This is supported by the location of both lymnaeid habitats in the same open drainage furrows, e.g. as shown in Figure 2. The second explanation is to consider that $G$. truncatula and $O$. glabra would tend to be mutually exclusive and that the former species would be a poor competitor compared with the latter. Økland (1990) reported that $G$. truncatula was seldom observed coexisting with another lymnaeid and that $O$. glabra showed increased frequency when no other freshwater gastropod species occurred in ditches and mires. Two other arguments support this hypothesis. The first is the competition between the two species for food acquisition when they are in the same breeding dishes in the laboratory, often resulting in the rapid death of G. truncatula when this snail grows in size (Dreyfuss et al., 2006). The second argument comes from observations reported by Dreyfuss et al. (2014) in several mixed communities with $G$. truncatula and $O$. glabra on acid soils. Compared with control habitats with either lymnaeid, the zone where $G$. truncatula lived in these mixed habitats was always reduced in area, while that with $O$. glabra did not show any significant difference. The behaviour of $G$. truncatula as a poor competitor could be related to its pioneering life history strategy (Taylor, 1965).

The density of overwintering $O$. glabra was significantly lower in habitats with $G$. fluitans than in those identified with any of the other five indicator species. This low number of adult individuals was also observed in G. truncatula habitats identified with G. Aluitans (Fig. 5), as $77 \%$ were colonized by $<10$ snails $/ \mathrm{m}^{2}$ in March 
or April (Rondelaud et al., 2011). These results suggest that conditions in a habitat identified with G. fluitans are not favourable for the development of a lymnaeid population. Again, two potentially complementary hypotheses can be proposed to explain this situation. The first relates to the quantity of food available for G. truncatula or O. glabra, which would probably be lower in the habitats identified with G. fluitans than in the other sites where either lymnaeid can live. The other hypothesis is to consider that this low density of snails would be due to the secondary metabolites that G. fluitans, like other submerged plants (Wetzel, 1969), can excrete through its submerged leaves and that these toxic substances would have a negative impact on snails and/or their food. Comparison of O. glabra densities was also performed with those reported by Rondelaud et al. (2011) for G. truncatula in the same farms on acid soils and during the same period of time (Fig. 5). The number of overwintering snails per $\mathrm{m}^{2}$ of habitat was clearly higher for $G$. truncatula than for the other lymnaeid, whatever the density class considered. Several hypotheses can be proposed to explain this difference between the densities of both lymnaeids. In our opinion, the most reliable explanation is to relate it to the characteristics of snail habitats and the ecology of each lymnaeid species. The amphibious behaviour of G. truncatula (Taylor, 1965) allows it to leave the water when living conditions are favourable and to move in search of food in a film of water (Moens, 1991). This feature would allow it to escape most of its terrestrial or aquatic predators and to take refuge in one or more environments depending on the nature of the predator. This would explain the high densities of overwintering G. truncatula found in March or April in its habitats. Conversely, the more aquatic behaviour of $O$. glabra would require it to live in deeper water collections than $G$. truncatula and to undergo greater predation with aquatic predators. This will result in lower densities of $O$. glabra in its habitats, even though the masses laid by this species are more numerous and contain more eggs than those of G. truncatula (Vareille-Morel et al., 1998; Titi et al., 2017).

In conclusion, $J$. effusus was the best indicator plant to detect the populations of $O$. glabra in most habitats on acid soils in central France. Larger snail habitats were noted in water points identified with either rush or L. uliginosus, while snail densities in March or April were lower in those identified with G. fluitans. However, the use of $J$. effusus as an indicator plant cannot be generalized to the other countries on acid soils because the conformation of meadows and pasture management vary with the breeding region and type of ruminants. Other investigations in the other areas on acid soils are still needed to determine whether there are limits before using this method in the field.

Acknowledgements. The authors gratefully thank the 361 farmers for having provided easy access to the sampling sites and assistance during the 36-year survey.

\section{References}

Abrous M., Rondelaud D., Dreyfuss G. and Cabaret J., 1999. Infection of Lymnaea truncatula and Lymnaea glabra by Fasciola hepatica and Paramphistomum daubneyi in farms of central France. Vet. Res., 30, 113-118.

Abrous M., Rondelaud D. and Dreyfuss G., 2000. A field study of natural infections in three freshwater snails with Fasciola hepatica and/or Paramphistomum daubneyi in central France. J. Helminthol., 74, 189-194.

Anderson R.M., 2013. The Population Dynamics of Infectious Diseases: Theory and Applications, Springer, New York, $368 \mathrm{p}$.

Becking R.W., 1957. The Zürich-Montpellier school of phytosociology. Bot. Rev., 23, 411-488.

Botineau M., 1985. Contribution à l'étude botanique de la haute vallée de la Vienne (phytogéographie, phytosociologie). Bull. Soc. Bot. Centre-Ouest, NS, 6, 1-352.

Brugel E., Brunerye L. and Vilks A., 2001. Plantes et végétation en Limousin: atlas de la flore vasculaire, Conservatoire Régional des Espaces Naturels du Limousin, Saint Gence, $863 \mathrm{p}$.

Charlier J., Soenen K., De Roeck E., Hantson W., Ducheyne E., Van Coillie F., De Wulf R., Hendrickx G. and Vercruysse J., 2014. Longitudinal study on the temporal and micro-spatial distribution of Galba truncatula in four farms in Belgium as a base for small-scale risk mapping of Fasciola hepatica. Parasit. Vect., 7, 528.

Crowley W., Harrison S.S.C., Coroi M. and Sacré V.M., 2003. An ecological assessment of the plant communities at Port Bán Natural Reserve in south-western Ireland. Biol. Environ. Proc. R. Ir. Acad., 103B, 69-82.

De Brie J., 1379. Le bon berger. Le vrai règlement et gouvernement des bergers et bergères. Rewritten in modern French by M. Clévenot in 1968. Editions Stock, Paris, 168 p.

De Vries V., 1945. Over het voorkommen van een 8-10 tal landslakjes op de westpunt van Vlieland. Basteria, 9, 44-60.

Dreyfuss G., Vareille-Morel C. and Rondelaud D., 1997. Les habitats de Lymnaea truncatula Müller (Mollusque) le long de deux rivières. Ann. Limnol. - Int. J. Lim., 33, 67-72.

Dreyfuss G., Vignoles P., Mekroud A. and Rondelaud D., 2006. The presence of uninfected Omphiscola glabra in a breeding of infected Galba truncatula enhanced the characteristics of snail infections with Fasciola hepatica. Parasitol. Res., 99, 197-199.

Dreyfuss G., Vignoles P. and Rondelaud D., 2014. Fasciola hepatica and Paramphistomum daubneyi: decrease in prevalence of natural infection in habitats colonized by Galba truncatula and Lymnaea glabra. Rev. Méd. Vét., 165, 160-166.

Gaultier E., Rondelaud D., Botineau M. and Ghestem A., 1994. La malacofaune des jonchaies prairiales dans le nord de la Creuse et le sud de l'Indre. Bull. Soc. Hist. Nat. Toulouse, 130, 15-19.

Ghestem A., Morel-Vareille C., Rondelaud D. and Vilks A., 1974. Premiers documents phytosociologiques des biotopes à Lymnaea (Galba) truncatula Müller (Mollusque Gastéropode) dans le nord-ouest du Limousin. Bull. Soc. Hist. Nat. Toulouse, 110, 235-240. 
Guy F., Rondelaud D., Botineau M., Dreyfuss G. and Ghestem A., 1996. Etude de relations entre les plantes les plus fréquentes et l'abondance de Lymnaea truncatula Müller, vecteur de Fasciola hepatica Linné dans les prairies marécageuses sur sol acide. Rev. Méd. Vét., 147, 465-470.

Hourdin P., Vignoles P., Dreyfuss G. and Rondelaud D., 2006. Galba truncatula (Gastropoda, Lymnaeidae): effects of daily water-level variations on the ecology and ethology of populations living upstream of a dam. Ann. Limnol. - Int. J. Lim., 42, 173-180.

Jourdin S., Rondelaud D., Descubes-Gouilly C. and Ghestem A., 1985. La distribution des Mollusques Pulmonés dans une prairie marécageuse est-elle dépendante de celle des groupements végétaux constitutifs? Bull. Soc. Hist. Nat. Toulouse, 121, 107-114.

Mas-Coma S., Valero M.A. and Bargues M.D., 2009. Fasciola, lymnaeids and human fascioliasis, with a global overview on disease transmission, epidemiology, evolutionary genetics, molecular epidemiology and control. Adv. Parasitol., 69, 41-146.

Mehl S., 1932. Die Lebensbedingungen der Leberegelschnecke (Galba truncatula Müller). Untersuchungen über Schale, Verbreitung, Lebensgeschichte, natürliche Feinde und Bekämpfungsmöglichkeiten. Arb. Bayer. Landes. Pflanzenbau Pflanzenschutz, 2, 1-177.

Moens R., 1981. Les habitats de Lymnaea truncatula, hôte intermédiaire de Fasciola hepatica. Rev. Agric. (Brussels), 34, 1563-1580.

Moens R., 1991. Factors affecting Lymnaea truncatula populations and related control measures. J. Med. Appl. Malacol., 3, 73-84.

Økland J., 1990. Lakes and Snails. Environment and Gastropods in 1,500 Norwegian Lakes, Ponds and Rivers, Universal Book Services/Dr. W. Backhuys, Oegstgeest, The Netherlands, 516 p.

Over H.J., 1962. A method of determining the liver fluke environment by means of the vegetation type. Bull. Off. Int. Epizoot., 58, 297-304.

Over H.J., 1967. Ecological biogeography of Lymnaea truncatula in the Netherlands. Doctorate thesis, University of Utrecht, $140 \mathrm{p}$.

Patzer H.E., 1927. Beiträge zur Biologie der Leberegelschnecke Galba (Limnaea) truncatula Müller. Zool. Jahrb. Abt. Allg. Zool. Physiol. Tiere, 53, 321-372.

R Core Team, 2016. R: a Language and Environment for Statistical Computing, R Foundation for Statistical Computing, Vienna, Austria. Available online at: https:// www.R-project.org (accessed 27 May 2016).
Roberts E.W., 1950. Studies on the life-cycle of Fasciola hepatica (Linnaeus) and of its snail host, Limnaea (Galba) truncatula Müller in the field and under controlled conditions. Ann. Trop. Med. Parasitol., 44, 187-206.

Rondelaud D., Vignoles P. and Dreyfuss G., 2009. La Limnée tronquée, un mollusque d'intérêt médical et vétérinaire, PULIM, Limoges, 283 p.

Rondelaud D., Hourdin P., Vignoles P., Dreyfuss G. and Cabaret J., 2011. The detection of snail host habitats in liver fluke infected farms by use of plant indicators. Vet. Parasitol., 181, 166-173.

Shapiro S.S. and Wilk M.B., 1965. An analysis of variance test for normality (complete samples). Biometrika, 52, 591-611.

Smith G., 1978. A field and laboratory study of the epidemiology of fascioliasis. PhD thesis, University of York, $185 \mathrm{p}$.

Taylor E.L., 1965. Fascioliasis and the liver-fluke, FAO Agricultural Studies, Roma, no. 64, 235 p.

Titi A., Mekroud M., Vignoles P., Dreyfuss G. and Rondelaud D., 2017. Insights into the reproductive activity of Omphiscola (Lymnaea) glabra (Gastropoda: Lymnaeidae) in relation to soil geology in central France. Ann. Limnol. - Int. J. Lim., 53, 11-17.

Torgerson P. and Claxton J., 1999. Epidemiology and control. In: Dalton J.P. (ed.), Fasciolosis, CABI Publishing, Oxon, 113-149.

Vareille-Morel C., Abrous M., Dreyfuss G. and Rondelaud D., 1998. Oviposition behaviour of Lymnaea truncatula in central France. J. Moll. Stud., 64, 387-391.

Vareille-Morel C., Dreyfuss G. and Rondelaud D., 1999. The characteristics of habitats colonized by three species of Lymnaea in swampy meadows on acid soil: their interest for fasciolosis control. Ann. Limnol. - Int. J. Lim., 35, 173-178.

Vareille-Morel C., Dreyfuss G. and Rondelaud D., 2007. Les habitats des Lymnaeidae sur sol acide. A propos de quelques observations dans la région Limousin sur une trentaine d'années. MalaCo, 4, 143-147.

Vignoles P., Rondelaud D. and Dreyfuss G., 2015. La Limnée étroite (Omphiscola glabra O.F. Müller, 1774) : variations numériques des mollusques adultes dans le centre de la France par rapport à la nature du sol et la présence d'autres Pulmonés aquatiques dans les mêmes habitats. MalaCo, 11, $1-5$.

Vignoles P., Dreyfuss G. and Rondelaud D., 2017. Ecologie et parasitisme de la Limnée étroite (Omphiscola glabra), PULIM, Limoges, 228 p.

Wetzel R., 1969. Excretion of dissolved organic compounds by aquatic macrophytes. Bioscience, 19, 539-540. 